\title{
Determinan Nilai Perusahaan Publik di Indonesia dan Filipina dengan Kepemilikan Institusional sebagai Pemoderasi
}

\author{
${ }^{1}$ Mia Julia Putri 2Nurmala Ahmar \\ ${ }^{1}$ Universitas Pancasila, Indonesia \\ 2 STIE Perbanas, Indonesia
}

I N F O A R T I K E L

JEL Classification:

M40

G30

\section{Keywords:}

price to book value.

\begin{abstract}
A B S T R A C T
Firm value is one the management's standard in managing the business. This study aims to scrutinize about determination value of enterprise public in indonesia and the philippines to the ownership of institutional as a moderator. Sample used in this research was the company into an LQ45 index in Indonesia and an PSEi30 index in the Philippines. Technique analysis the data used was structural equation modelling-partial least square (SEM-PLS) using warppls 6.0. It is also done analysis multigrup to see if there is a difference in the influence of profitability, the solvability and the size of the company on the companies in Indonesia and the Philippines. The results of testing shows that its satisfactory profitability as to depend on the value of enterprise in Indonesia and the Philippines.The solvability has not been affecting the value of enterprise in Indonesia and the Philippines. For variables the size of the company, or is the size of the striking result. Itis to depend on the value of enterprise in the Philippines, while in Indonesia do not affect the size of the company. Following the completion of variable moderation or testing by adding the results showed that in Indonesia, institutional ownership capable of moderating influence on the perceived value of the company profitability, while in the Philippines ownership of moderating the influence of institutional capable of reducing the size of the company on the perceived value of the company. The results of the analysis multigrup show there is a difference of determination value of enterprise in Indonesia and the Philippines to the ownership of institutional as an moderation variable.
\end{abstract}

\section{A B S T R A K}

Studi ini bertujuan untuk meneliti mengenai determinasi nilai perusahaan publik di Indonesia dan Filipina dengan kepemilikan institusional sebagai pemoderasi. Sampel yang digunakan dalam penelitian ini adalah perusahaan yang masuk ke dalam indeks LQ45 di Indonesia dan indeks PSEi30 di Filipina. Teknik analisis data yang digunakan adalah Structural Equation Modelling-partial Least Square (SEM-PLS) dengan menggunakan program WarpPLS 6.0. analisis multigrup untuk mengetahui apakah ada perbedaan pengaruh profitabilitas, solvabilitas dan ukuran perusahaan terhadap nilai perusahaan di Indonesia dan Filipina.Hasil pengujian menunjukkan bahwa profitabilitas berpengaruh terhadap nilai perusahaan di Indonesia dan Filipina. Solvabilitas tidak berpengaruh terhadap nilai perusahaan di Indonesia dan Filipina. Untuk variabel ukuran perusahaan, hasil yang didapatkan adalah ukuran berpengaruh terhadap nilai perusahaan di Filipina, sedangkan di Indonesia ukuran perusahaan tidak berpengaruh. Setelah dilakukan pengujian dengan menambahkan variabel moderasi didapatkan hasil bahwa di Indonesia, kepemilikan institusional mampu memoderasi pengaruh profitabilitas terhadap nilai perusahaan, sedangkan di Filipina kepemilikan institusional mampu memoderasi pengaruh profitabilitas dan ukuran perusahaan terhadap nilai perusahaan. Hasil analisis multigrup menunjukkan terdapat perbedaan determinasi nilai perusahaan di Indonesia dan Filipina dengan kepemilikan institusional sebagai pemoderasi. 


\section{Pendahuluan}

Setiap perusahaan yang didirikan pasti memiliki tujuan yang jelas. Tujuan yang utama adalah untuk dapat memaksimalkan laba, selain itu juga bertujuan untuk memaksimalkan nilai perusahaan yang ditunjukkan dari harga saham. Menurut Suratno (2017) tujuan utama setiap entitas bisnis adalah meningkatkan nilai-nilai perusahaan, karena nilai-nilai perusahaan dapat mencerminkan efektifitas organisasi bisnis. Memaksimalkan nilai perusahaan sangat penting artinya bagi suatu perusahaan, karena dengan memaksimalkan nilai perusahaan berarti juga memaksimalkan kemakmuran pemegang saham yang merupakan tujuan utama perusahaan (Munawaroh, dkk, 2014).

Ada beberapa faktor yang mempengaruhi Nilai Perusahaan, diantaranya adalah profitabilitas, solvabilitas dan ukuran perusahaan. Nilai perusahaan dapat dipengaruhi oleh besar kecilnya profitabilitas yang dihasilkan perusahaan, apabila profitabilitas perusahaan baik maka para stakeholder yang terdiri dari kreditur, supplier dan juga investor akan melihat sejauh mana perusahaan dapat menghasilkan laba dari penjualan dan investasi perusahaan (Samosir, 2017).

Solvabilitas (kebijakan hutang) juga dapat dihubungkan dengan nilai perusahaan.Kebijakan hutang merupakan kebijakan perusahaan tentang seberapa jauh sebuah perusahaan menggunakan pendanaan hutang, semakin tinggi proporsi hutang maka semakin tinggi harga saham perusahaan tersebut (Mardiyati, dkk, 2012). Dengan adanya Debt yang besar manajemen berupaya meningkatkan laba agar perusahaan dapat membayarkan kewajibannya (Ali\& Miftahurrohman, 2014). Nilai perusahaan juga dapat dipengaruhi oleh ukuran perusahaan. Ukuran perusahaan dianggap mampu mempengaruhi nilai perusahaan karena semakin besar skala perusahaan maka akan semakin mudah perusahaan memperoleh sumber pendanaan baik yang bersifat internal maupun eksternal (Prasetyorini, 2013). Ukuran perusahaan disini dilihat dari total asset yang dimiliki perusahaan yang dapat diipergunakan untuk kegiatan operasi perusahaan. Menurut Tommy dan Saerang (2014) jika perusahaan memiliki total asset yang besar, pihak manajemen lebih leluasa dalam mempergunakan asset yang ada di perusahaan tersebut.

Nilai perusahaan dapat diukur dengan beberapa cara, salah satunya adalah dengan Price to Book Value (PBV). Price to Book Value (PBV) menggambarkan seberapa besar pasar menghargai nilai buku saham suatu perusahaan, dengan kata lain semakin tinggi tingkat kepercayaan pasar terhadap prospek perusahaan maka akan menjadi daya tarik bagi investor untuk membeli saham tersebut sehingga permintaan akan naik, kemudian mendorong harga saham menjadi naik juga (Ayuningrum, 2016). Naik turunnya PBV yang terjadi di Indonesia maupun Filipina terjadi disebabkan oleh banyak faktor, diantaranya kondisi perekonomian, tingkat inflasi, nilai tukar (exchange rate), tingkat investasi, pertumbuhan ekonomi ataupun juga tingkat hutang suatu Negara.

Penelitian mengenai faktor-faktor yang mempengaruhi nilai perusahaan telah dilakukan sebelumnya, seperti profitabilitas yang diproksikan dengan ROA. Dari hasil penelitian yang dilakukan oleh Mawati, dkk (2017), Ayuningrum (2016), yang membuktikan bahwa Return on Assets (ROA) berpengaruh signifikan terhadap nilai perusahaan. Sedangkan menurut Wardoyo \& Agustini (2015) didapatkan hasil bahwa Return on Assets (ROA) tidak memiliki pengaruh terhadap nilai perusahaan.

Penelitian yang dilakukan oleh Samsosir (2017), Wardoyo \& Agustini (2015), Munawaroh \& Priyadi (2014), Dewi \& Wirajaya (2013), Mardiyati, dkk (2012), dan Dj, dkk (2012), dinyatakan bahwa Return on Equity (ROE) berpengaruh signifikan terhadap nilai perusahaan. Namun hasil tersebut berbeda dengan penelitian yang dilakukan oleh Yusrianti, dkk (2016), bahwa Return on Equity (ROE) tidak berpengaruh terhadap nilai perusahaan.

Penelitian mengenai pengaruh Net Profit Margin (NPM) yang dilakukan oleh Dini \& Indarti (2012), diketahui bahwa NPM tidak berpengaruh terhadap nilai perusahaan. Tetapi berbeda dengan hasil penelitian yang dilakukan oleh Irayanti \& Tumbel (2014) dan Munawaroh \& Priyadi (2014), bahwa Net Profit Margin (NPM) berpengaruh secara signifikan terhadap nilai perusahaan.

Kebijakan hutang dapat diproksikan melalui Debt to Equity Ratio (DER). Seperti penelitian yang telah dilakukan sebelumnya oleh Samosir (2017), Irayanti \& Tumbel (2014), Ali \& Miftahurrohman (2014), Dewi \& Wirajaya (2013), bahwa DER memiliki pengaruh signifikan positif terhadap nilai perusahaan. Sedangkan hasil yang berbeda ditunjukkan oleh penelitian dari Tommy dan Saerang (2014), Siahaan (2017), Mardiyati, 
dkk (2012) dan Dj, dkk (2012), dimana DER tidak memiliki pengaruh terhadap nilai perusahaan.

Sedangkan penelitian mengenai pengaruh DAR terhadap nilai perusahaan sebelumnya juga pernah dilakukan oleh Hoque, dkk (2014), bahwa DAR berpengaruh signifikan positif terhadap nilai perusahaan. Tetapi hasil yang berbeda didapatkan oleh Siahaan (2017) yaitu DAR tidak berpengaruh terhadap nilai perusahaan.

Ukuran perusahaan juga merupakan salah satu faktor yang dapat mempengaruhi nilai perusahaan. Dari hasil penelitian yang dilakukan oleh Mawati, dkk (2017), Tommy dan Saerang (2014) dan Siahaan (2017), ukuran perusahaan memiliki pengaruh signifikan positif terhadap nilai perusahaan. Sedangkan menurut Dewi \& Wirajaya (2013), dihasilkan bahwa ukuran perusahaan tidak berpengaruh terhadap nilai perusahaan. Nilai tambah dalam penelitian ini, penulis menambahkan variabel moderasi, yaitu struktur kepemilikan yang diproksikan oleh kepemilikan institusional (institutional ownership). Tingkat kepemilikan oleh institusional (institutional ownership) yang merupakan pemegang saham dari unsur investor dan merupakan pemegang saham yang paling mendominasi struktur kepemilikan saham perusahaan-perusahaan go public Indonesia didominasi oleh perusahaan-perusahaan holding company yang saling berafiliasi bahkan para pemegang saham dari perusahaan-perusahaan holding company tersebut masih memiliki hubungan keluarga bahkan dengan pihak manajemen perusahaan (Ali \& Miftahurrohman, 2014).

Kepemilikian institusi yang terdapat pada perusahaan memungkinkan perusahaan untuk mendorong peningkatan pengawasan (monitoring) yang lebih efektif dan efisien atas kinerja agen perusahaan dan insiders, sehingga dengan meningkatnya kinerja perusahaan akan mendorong peningkatan nilai perusahaan.

Pada penelitian yang dilakukan oleh Ali \& Miftahurrohman (2014) dengan struktur kepemilikan sebagai variabel independen, didapatkan bahwa struktur kepemilikan tidak memiliki pengaruh terhadap nilai perusahaan. Sedangkan dari haril penelitian yang dilakukan oleh Ayuningrum (2016), struktur kepemilikan memiliki pengaruh signifikan positif terhadap nilai perusahaan.

Penelitian dengan kepemilikan institusional sebagai variabel moderasi sebelumnya dilakukan oleh Suta \& Agustina (2016), dimana kepemilikan institusional memiliki pengaruh signifikan yang kuat dalam mempengaruhi hubungan antara kebijakan hutang dan nilai perusahaan.

\section{Telaah Teori dan Pengembangan Hipotesis Pengaruh Profitabilitas dengan Nilai Perusahaan}

Penelitian mengenai pengaruh profitabilitas dalam hal ini diproksikan melalui ROA, ROE dan NPM. Pengaruh ROA terhadap Nilai Perusahaan sebelumnya telah dilakukan oleh Ayuningrum (2016), yang membuktikan bahwa ROA (Return on Assets) berpengaruh signifikan terhadap nilai perusahaan. Hasil yang sama juga ditemukan oleh Putri, dkk (2016) bahwa ROA (Return on Assets) berpengaruh signifikan terhadap nilai perusahaan. Penelitian yang telah dilakukan oleh Samosir (2017) menunjukkan bahwa ROE berpengaruh signifikan positif terhadap nilai perusahaan. Sama halnya dengan penelitian yang dilakukan oleh Munawaroh dan Priyadi (2014) bahwa ROE berpengaruh signifikan positif terhadap nilai perusahaan. Penelitian tentang pengaruh NPM terhadap nilai perusahaan telah dilakukan sebelumnya oleh Irayanti \& Tumbel (2014) dan Munawaroh dan Priyadi (2014) sama-sama menunjukkan hasil yg konsisten, dimana NPM berpengaruh secara signifikan positif terhadap nilai perusahaan.

Tingginya profitabilitas pada suatu perusahaan akan meningkatkan EPS, EPS yang tinggi akan memberikan respon positif dipasar, maka permintaan akan saham akan ikut meningkat, permintaan yang meningkat akan meningkatkan harga saham sehingga nilai perusahaan akan meningkat.

H1a : Profitabilitas berpengaruh signifikan positif terhadap Nilai Perusahaan di Indonesia $\mathrm{H} 1 \mathrm{~b}$ : Profitabilitas berpengaruh signifikan positif terhadap Nilai Perusahaan di Filipina

\section{Pengaruh Solvabilitas dengan Nilai Perusahaan}

Ali \& Miftahurrohman (2014) dalam penelitiannya menghasilkan bahwa Debt to Equity Ratio (DER) berpengaruh signifikan positif terhadap nilai perusahaan. Hasil yang sama dengan penelitian yang dilakukan oleh Irayanti \& Tumbel (2014), Samosir (2017), Dewi dan Wirajaya (2013) bahwa DER berpengaruh signifikan positif terhadap nilai perusahaan. 
Penelitian mengenai pengaruh Debt to Assets Ratio (DAR) yang sebelumnya telah dilakukan oleh Hoque, dkk (2014), bahwa DAR berpengaruh signifikan positif terhadap nilai perusahaan. Hasil yang sama juga didapatkan dari penelitian yang dilakukan oleh Ruan, dkk (2011) dimana DAR berpengaruh signifikan positif terhadap nilai perusahaan.

Hasil yang positif menunjukkan bahwa setiap kenaikan solvabilitas, maka kemampuan perusahaan dalam membayarkan kewajibannya juga positif, sehingga memberikan sinyal positif di mata investor. Para investor akan mau menanamkan modalnya pada perusahaan tersebut, banyaknya permintaan saham dari investor akan meningkatkan nilai saham pada perusahaan, maka secara langsung juga akan meningkatkan nilai perusahaan tersebut.

$\mathrm{H} 2 \mathrm{a}$ : Solvabilitas berpengaruh signifikan positif terhadap Nilai Perusahaan di Indonesia

$\mathrm{H} 2 \mathrm{~b}$ : Solvabilitas berpengaruh signifikan positif terhadap Nilai Perusahaan di Filipina

\section{Pengaruh Ukuran Perusahaan dengan Nilai Perusahaan}

Ukuran perusahaan merupakan salah satu indikasi mengukur kinerja suatu perusahaan, dimana juga dapat mempengaruhi nilai suatu perusahaan. Ukuran perusahaan yang besar dapat mencerminkan jika perusahaan mempunyai komitmen tinggi untuk terus memperbaiki kinerjanya, sehingga pasar akan mau membayar lebih mahal untuk mendapatkan sahamnya karena percaya akan mendapatkan pengembalian yang menguntungkan dari perusahaan tersebut.

Dari hasil penelitian yang dilakukan oleh Mawati, dkk (2017), ukuran perusahaan memiliki pengaruh signifikan positif terhadap nilai perusahaan. Hasil yang sama juga ditemukan oleh Siahaan (2017) dimana ukuran perusahaan berpengaruh signifikan positif terhadap nilai perusahaan. Ukuran perusahaan yang besar akan membuat para investor yakin untuk menanamkan modalnya, dengan kata lain nilai saham akan meningkat, dan nilai perusahaan ikut meningkat juga.

H3a : Ukuran Perusahaan berpengaruh signifikan positif terhadap Nilai Perusahaan di Indonesia $\mathrm{H} 3 \mathrm{~b}$ : Ukuran Perusahaan berpengaruh signifikan positif terhadap Nilai Perusahaan di Filipina

Pengaruh Kepemilikan Institusional dengan Nilai Perusahaan
Penelitian mengenai pengaruh struktur kepemilikan (kepemilikan isntitusional) terhadap nilai perusahaan sebelumnya yang dilakukan oleh Ayuningrum (2016), bahwa kepemilikan institusional berpengaruh signifikan positif terhadap nilai perusahaan.

Hasil yang positif menunjukkan bahwa semakin tinggi kepemilikan institusi akan mendorong peningkatan pengawasan yang lebih efektif dan efisien, hal ini akan meningkatkan produktivitas perusahaan, laba meningkat sehingga EPS juga meningkat. EPS meningkat akan memberikan respon yang positif oleh pasar, permintaan saham akan ikut meningkat, harga saham akan meningkat dan akan membuat nilai perusahaan ikut meningkat.

H4a : Kepemilikan Institusional berpengaruh terhadap Nilai Perusahaan di Indonesia

$\mathrm{H} 4 \mathrm{~b}$ : Kepemilikan Institusional berpengaruh terhadap Nilai Perusahaan di Filipina

\section{Peran Pemoderasi Kepemilikan Institusional terhadap Pengaruh Profitabilitas, Solvabilitas dan Ukuran Perusahaan terhadap Nilai Perusahaan}

Adanya investor institusi di dalam suatu perusahaan akan melakukan monitoring yang lebih pada perusahaan, seperti kinerja perusahaan, tingkat laba perusahaan. Hal ini akan mendorong manajemen perusahaan untuk meningkatkan kinerja perusahaan, kinerja perusahaan yang tinggi dapat meningkatkan profitabilitas perusahaan, sehingga besarnya kepemilikan institusional dapat memperkuat pengaruh profitabilitas terhadap nilai perusahaan. Adanya investor institusi di dalam suatu perusahaan akan membuat manajemen perusahaan lebih berhati-hati dalam melakukan kebijakan perusahaan, seperti kebijakan hutang. Sehingga kepemilikan institusional yang tinggi akan mampu meningkatkan nilai perusahaan.

Dilihat dari keadaan ekonomi, karakteristik antara Indonesia dan Filipina akan mengakibatkan adanya perbedaan pengaruh profitabilitas, solvabilitas dan ukuran perusahaan terhadap nilai perusahaan dengan kepemilikian institusional sebagai pemoderasi.

$\mathrm{H} 5 \mathrm{a}$ : Kepemilikan Institusional mampu memoderasi Profitabilitas terhadap Nilai Perusahaan di Indonesia

$\mathrm{H} 5 \mathrm{~b}$ : Kepemilikan Institusional mampu memoderasi Profitabilitas terhadap Nilai Perusahaan di Filipina 
H6a : Kepemilikan Institusional mampu memoderasi Solvabilitas terhadap Nilai Perusahaan di Indonesia

$\mathrm{H6b}$ : Kepemilikan Institusional mampu memoderasi Solvabilitas terhadap Nilai Perusahaan di Filipina

$\mathrm{H7a}$ : Kepemilikan Institusional mampu memoderasi Ukuran Perusahaan terhadap Nilai Perusahaan di Indonesia

$\mathrm{H7b}$ : Kepemilikan Institusional mampu memoderasi Ukuran Perusahaan terhadap Nilai Perusahaan di Filipina

H8 : Terdapat perbedaan Pengaruh Determinasi Nilai Perusahaan dengan Kepemilikan Institusional sebagai Pemoderasi di Indonesia dan Filipina

\section{Metode Penelitian}

Peneliti menggunakan metode kuantitatif dimana data-data penelitian berupa angka dan analisis menggunakan statistik. Penelitian ini merupakan explanatory research yang ditujukan untuk menguji dan menganalisis hubungan sebab akibat antara variabel eksogen dengan variabel endogen, sehingga model penelitian dapat dijadikan sarana yang tidak bias serta menguji teori-teori yang berhubungan dengan penelitian. Populasi yang digunakan dalam penelitian ini adalah Perusahaan Go Public yang terdaftar di Bursa Efek Indonesia dan Filipina, dengan sampel adalah perusahaan yang terdaftar dalam Index LQ45 di BEI dan PSEi30 di PSE Filipina dengan menggunakan metode purposive sampling sehingga mendapatkan total sampel sebanyak 260.

Teknik analisis data yang digunakan dalam penelitian ini adalah metode Structural Equation Modeling (SEM) dengan pendekatan Partial Least Square (PLS) dan analisis multigrup dengan program WarpPLS 6.0 untuk menguji perbedaan pengaruh determinasi nilai perusahaan antara Indonesia dengan Filipina. Langkah pengujian yang dilakukan pada PLS adalah analisis statistik deskriptif, uji outer model, dan uji inner model. Sedangkan untuk analisis multigrup dilakukan dengan beberapa langkah yaitu menghitung pooled standard error, menghitung nilai kritis, menentukan nilai signifikansi, melakukan analisa dan membuat kesimpulan.

Variabel-variabel yang digunakan dalam penelitian ini adalah sebagai berikut :

\section{Definisi Operasional Variabel}

\begin{tabular}{|c|c|c|c|c|}
\hline No & $\begin{array}{c}\text { Nama } \\
\text { Variabel }\end{array}$ & Definisi & Pengukuran & Rujukan \\
\hline \multirow[t]{3}{*}{1.} & Price to Book & Pandanganinvestor & & Tommy \\
\hline & Value (PBV) & mengenai performance & Harga Saham & dan \\
\hline & (Endogen $)$ & perusahaan & $\overline{\text { Nilai Buku Saham }}$ & $\begin{array}{l}\text { Saerang } \\
(2014)\end{array}$ \\
\hline \multirow[t]{4}{*}{2.} & Return on & Kemampuan perusahaan & & \\
\hline & Assets (ROA) & menghasilkan laba dari aset & Net Profit & Munawar \\
\hline & $\left(\right.$ Eksogen $\left._{1}\right)$ & yang dimanfaatkan & $\overline{\text { Total Asset }}$ & oh dan \\
\hline & & & & $\begin{array}{l}\text { Priyadi } \\
(2014)\end{array}$ \\
\hline \multirow[t]{4}{*}{3.} & Return on & Kemampuan & & \\
\hline & Equity (ROE) & menghasilkan laba & & Munawar \\
\hline & $\left(\right.$ Eksogen $\left._{2}\right)$ & dibandingkan dengan jumlah & Net Profit & oh dan \\
\hline & & $\begin{array}{l}\text { modal yang dimiliki } \\
\text { perusahaan }\end{array}$ & $\overline{\text { Total Equity }}$ & $\begin{array}{l}\text { Priyadi } \\
(2014)\end{array}$ \\
\hline \multirow[t]{3}{*}{4.} & Net Profit & Kemampuan & & \\
\hline & Margin (NPM) & dalam menghasilkan net & & Munawar \\
\hline & $\left(\right.$ Eksogen $\left._{3}\right)$ & 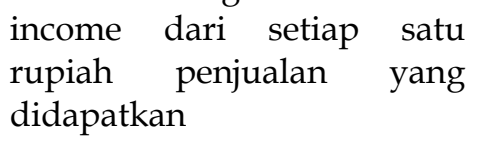 & $\frac{\text { Net Profit }}{\text { Net Sales }} \times 100 \%$ & $\begin{array}{l}\text { oh dan } \\
\text { Priyadi } \\
(2014)\end{array}$ \\
\hline 5. & $\begin{array}{l}\text { Debt to Asset } \\
\text { Ratio (DAR) } \\
\text { (Eksogen })\end{array}$ & $\begin{array}{l}\text { Gambaran seberapa banyak } \\
\text { asset perusahaan dapat } \\
\text { digunakan untuk melunasi } \\
\text { hutangnya. }\end{array}$ & $\frac{\text { Total Liability }}{\text { Total Asset }} \times 100 \%$ & $\begin{array}{l}\text { Hoque, } \\
\text { dkk (2014) }\end{array}$ \\
\hline
\end{tabular}


6. Debt to Asset Kemampuan perusahaan

Ratio (DER) untuk melunasi hutang-

(Eksogen 5$) \quad$ hutangnya yang dibiayai dari

harta pemegang saham

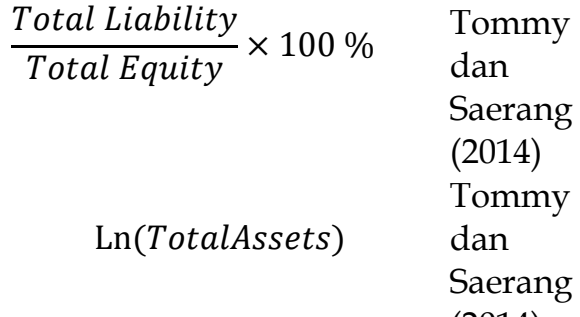

(2014)

Wibowo, dkk (2016) $\sum \%$ Inst. Ownership

8. KepemilikanI Saham perusahaan yang nstitusional dimiliki oleh institusi atau (Moderating) lembaga (perusahaan asuransi, bank, perusahaan investasi, dan institusi lain).

\section{Hasil dan Pembahasan}

Penelitian ini dilakukan analisis deskriptif bertujuan untuk mengetahui karateristik dari variabel-variabel yang ada dalam penelitian ini. Berikut adalah deskriptif nilai ratarata variabel penelitian di Indonesia dan Filipina :

Statistik Deskriptif Variabel Penelitian Tahun 2012 - 2016

\begin{tabular}{lllllllll}
\hline \multirow{2}{*}{ Variabel } & \multicolumn{2}{c}{ Minimum } & \multicolumn{2}{c}{ Maksimum } & \multicolumn{2}{c}{ Mean } & \multicolumn{2}{c}{ Standar Deviasi } \\
\cline { 2 - 9 } & Indo & Filipina & Indo & Filipina & Indo & Filipina & Indo & Filipina \\
\hline ROA & 1.41 & .10 & 71.51 & 18.31 & 10.60 & 5.58 & 9.33 & 3.85 \\
ROE & 4.50 & 2.10 & 135.85 & 92.40 & 21.56 & 15.83 & 21.97 & 9.99 \\
NPM & 2.76 & 0.00 & 71.73 & 55.77 & 19.41 & 17.70 & 11.70 & 10.95 \\
DAR & 0.17 & 0.24 & 1.21 & 0.91 & 0.50 & 0.60 & 0.21 & 0.15 \\
DER & 0.20 & 0.31 & 7.52 & 9.69 & 1.72 & 2.31 & 2.10 & 2.46 \\
T.A & 15.15 & 10.50 & 20.76 & 14.66 & 17.69 & 12.60 & 1.38 & 0.98 \\
KI.NK & 0.00 & 0.00 & 85.00 & 78.20 & 24.89 & 33.22 & 28.13 & 30.72 \\
KI.K & 0.00 & 0.00 & 80.53 & 75.98 & 20.38 & 14.58 & 28.40 & 21.44 \\
PBV & 0.36 & 0.11 & 58.48 & 8.43 & 4.64 & 2.56 & 8.79 & 1.57 \\
\hline
\end{tabular}

Nilai rata-rata Return on Asset (ROA) di Indonesia sebesar 10,6\% sedangkan di Filipina yaitu 5,58\%, hal ini menunjukkan bahwa rata-rata perusahaan di Indonesia memiliki kemampuan yang lebih baik dalam menghasilkan laba dari penggunaan asset dibandingkan dengan perusahaan di Filipina. Nilai rata-rata Return on Equity (ROE) di Indonesia sebesar $21,56 \%$ sedangkan di Filipina yaitu $15,83 \%$, hal ini menunjukkan bahwa ratarata perusahaan di Indonesia memiliki kemampuan yang lebih baik dalam menghasilkan laba dari jumlah modal yang dimiliki dibandingkan dengan Perusahaan di Filipina. Nilai rata-rata Net Profit Margin (NPM) di Indonesia sebesar $19,41 \%$ dan di Filipina sebesar $17,70 \%$, hal ini menunjukkan bahwa rata-rata perusahaan di Indonesia memiliki kemampuan yang lebih baik dalam menghasilkan laba dari pendapatan yang diperoleh dibandingkan dengan perusahaan di Filipina.

Nilai rata-rata Debt to Asset Ratio (DAR) dan Debt to Equity Ratio (DER) di Filipina lebih tinggi dibandingkan di Indonesia, hal ini menunjukkan bahwa rata-rata perusahaan di Filipina menerapkan kebijakan hutang yang cukup tinggi dibandingan perusahaan di Indonesia.

Nilai rata-rata kepemilikan institusional di Indonesia adalah 45,27 yang terbagi dalam lembaga keuangan sebesar 20,38 dan lembaga non keuangan sebesar 24,89. Sedangkan di Filipina rata-rata kepemilikan institusional adalah sebesar 47.80 yang terbagi dalam lembaga non keuangan sebesar 33,22 dan lembaga keuangan 14.58. Dari hasil tersebut menunjukkan bahwa kepemilikan institusional lembaga non keuangan dan lembaga 
keuangan di kedua Negara tidak dominan karna masih kurang dari 50.

Nilai perusahaan yang ditunjukkan dengan nilai Price to Book Value (PBV) pada tabel diatas menunjukkan Indonesia memiliki PBV sebesar 4,64 dan di Filipina 2,56, hal ini berarti
Indonesia memiliki nilai PBV yang lebih tinggi dibandingkan dengan di Filipina.

Perbandingan hasil pengujian model struktural di Indonesia dan Filipina dengan dan tanpa variabel kontrol dapat dilihat di tabel berikut :

Perbandingan Hasil Pengujian Full Model di Indonesia dan Filipina

\begin{tabular}{|c|c|c|c|c|}
\hline \multirow{2}{*}{ Pengaruh } & \multicolumn{2}{|c|}{ Indonesia } & \multicolumn{2}{|c|}{ Filipina } \\
\hline & Model 1 & Model 2 & Model 1 & Model 2 \\
\hline Profit & $<0.01^{*}$ & $<0.01^{*}$ & $<0.01^{*}$ & $<0.01^{*}$ \\
\hline Solv & 0.44 & 0.42 & 0.23 & 0.24 \\
\hline T.A & 0.40 & 0.38 & $<0.01^{*}$ & $<0.01^{*}$ \\
\hline KI & 0.37 & 0.37 & $<0.01^{*}$ & $<0.01^{*}$ \\
\hline Profit*KI & $<0.01^{*}$ & $<0.01^{*}$ & $<0.01^{*}$ & $<0.01^{*}$ \\
\hline Solv*KI & 0.39 & 0.38 & 0.17 & 0.18 \\
\hline T.A*KI & 0.40 & 0.42 & $0.08^{*}$ & $0.08^{*}$ \\
\hline EkonomiMakro & - & 0.37 & - & 0,21 \\
\hline R Square $\left(\mathrm{R}^{2}\right)$ & $94 \%$ & $95 \%$ & $27 \%$ & $26 \%$ \\
\hline
\end{tabular}

Ket : Model 1 (tanpa Variabel Kontrol)

Model 2 (dengan variabel kontrol)

*) Signifikan

Setelah dilakukan pengujian model struktural dengan variabel kontrol dan tanpa variabel kontrol, didapatkan hasil bahwa variabel ekonomi makro sebagai variabel kontrol tidak

berpengaruh signifikan terhadap nilai perusahaan.

Hasil pengujian hipotesis dapat di rangkum sebagai berikut :

Hasil Pengujian Hipotesis di Indonesia dan Filipina

\begin{tabular}{lllll}
\hline \multirow{2}{*}{ Hipotesis Penelitian } & \multicolumn{2}{c}{ Indonesia } & \multicolumn{2}{c}{ Filipina } \\
\cline { 2 - 5 } & $\begin{array}{c}\text { P- } \\
\text { Value }\end{array}$ & \multicolumn{1}{c}{ Keterangan } & P-Value & Keterangan \\
\hline H1 & $<0,01^{*}$ & Terbukti & $<0,01^{*}$ & Terbukti \\
H2 & 0,42 & Tidak Terbukti & 0,24 & Tidak Terbukti \\
H3 & 0,38 & Tidak Terbukti & $<0,01^{*}$ & Terbukti \\
H4 & 0,37 & Tidak Terbukti & $<0,01^{*}$ & Terbukti \\
H5 & $<0,01^{*}$ & Terbukti & $<0,01^{*}$ & Terbukti \\
H6 & 0,38 & Tidak Terbukti & 0,18 & Tidak Terbukti \\
H7 & 0,42 & Tidak Terbukti & $0,08^{* *}$ & Terbukti \\
\hline
\end{tabular}

Sumber :Hasil Warp PLS (data diolah) *) sign 5\%, **) sign 10\%

Dari hasil pengujian hipotesis didapatkan bahwa profitabilitas berpengaruh terhadap nilai perusahaan, baik di Indonesia maupun di Filipina. Dalam penelitian ini profitabilitas diproksikan oleh Return on Asset (ROA), Return on Equity (ROE) danNet Profit Margin (NPM). Suatu perusahaan yang memiliki tingkat profitabilitas tinggi, akan mengakibatkan nilai Earning per Share (EPS) yang tinggi, EPS yang tinggi akan meningkatkan respon pasar sehingga permintaan (Demand) meningkat, harga saham perusahaan akan ikut meningkat, sehingga nilai perusahaan pun akan meningkat. Begitu juga sebaliknya, saat profitabilitas turun, EPS turun, respon pasar 
menurun, demand tidak meningkat, harga saham cenderung turun atau tetap, dan mengakibatkan nilai perusahaan tidak meningkat.

Variabel solvabilitas tidak berpengaruh terhadap nilai perusahaan dan hubungannya positif, baik di Indonesia maupun di Filipina. Hal ini dapat terjadi karena suatu perusahaan yang memiliki solvabilitas tinggi, maka biaya-biaya yang harus dikeluarkan perusahaan seperti biaya bunga pinjaman yang tinggi, biaya cicilan pinjaman sehingga perusahaan tidak mampu meningkatkan laba perusahaan yang berarti EPS tidak akan meningkat, permintaan turun, harga saham turun maka nilai perusahaan akan ikut turun. Koefisien yang positif berarti saat solvabilitas naik maka nilai perusahaan akan turun, begitu juga sebaliknya saat solvabilitas turun maka nilai perusahaan akan naik.

Hipotesis pengaruh ukuran perusahaan terhadap nilai perusahaan di Indonesia menunjukkan bahwa ukuran perusahaan tidak berpengaruh terhadap nilai perusahaan. Hasil ini sejalan dengan penelitian yang sebelumnya dilakukan oleh Dewi \& Wirajaya (2013), dimana ukuran perusahaan tidak berpengaruh terhadap nilai perusahaan.Sedangkan pengujian mengenai pengaruh ukuran perusahaan terhadap nilai perusahaan di Filipina menunjukkan bahwa, ukuran perusahaan berpengaruh terhadap nilai perusahaan. Hal ini sejalan dengan hasil penelitian dari Mawati, dkk (2017), Tommy dan Saerang (2014), dan Siahaan (2017) bahwa ukuran perusahaan berpengaruh signifikan terhadap nilai perusahaan. Ukuran perusahaan yang besar akan membuat para investor yakin untuk menanamkan modalnya, dengan kata lain nilai saham akan meningkat, dan nilai perusahaan ikut meningkat juga.

Pengaruh kepemilikan institusional terhadap nilai perusahaan di Indonesia menunjukkan bahwa yaitu kepemilikan institusional tidak berpengaruh terhadap nilai perusahaan.Kesimpulannya semakin besar proporsi kepemilikan institusi pada suatu perusahaan tidak akan berdampak pada nilai perusahaan suatu Negara. Sedangkan pengujian mengenai pengaruh kepemilikan institusional terhadap nilai perusahaan di Filipina menunjukkan bahwa kepemilikan institusional berpengaruh terhadap nilai perusahaan. Semakin tinggi kepemilikan institusional akan mendorong peningkatan pengawasan yang lebih efektif dan efisien, sehingga akan meningkatkan permintaan saham pada para investor yang berakibat semakin tinggi juga nilai perusahaan tersebut.

Setelah ditambahkan variabel moderasi, profitabilitas mampu memoderasi profitabilitas terhadap nilai perusahaan di Indonesia dan Filipina.Hasil penelitian ini menunjukkan bahwa apabila nilai profitabilitas suatu perusahaan tinggi, diikuti dengan besarnya kepemilikan institusional maka akan mempengaruhi nilai perusahaan. Kepemilikian institusi yang terdapat pada perusahaan memungkinkan perusahaan untuk mendorong peningkatan pengawasan (monitoring) yang lebih efektif dan efisien atas kinerja agen perusahaan dan insiders, sehingga dengan meningkatnya kinerja perusahaan akan mendorong peningkatan laba perusahaan, respon pasar meningkat, permintaan akan saham meningkat, harga saham meningkat sehingga nilai perusahaan juga akan meningkat.

Setelah ditambahkan variabel moderasi, pengaruh solvabilitas terhadap nilai perusahaan dengan kepemilikan institusional sebagai pemoderasi di Indonesia dan Filipina menunjukkan bahwa H6a dan H6b ditolak, dimana kepemilikan institusional tidak mampu memoderasi pengaruh solvabilitas terhadap nilai perusahaan. Hal ini berarti besarnya kepemilikan institusional di dalam suatu perusahaan tidak mampu memoderasi pengaruh solvabilitas terhadap nilai perusahaan, hal ini karena perusahaan dengan solvabilitas besar tidak mampu meningkatkan laba perusahaan, respon pasar menurun, permintaan menurun, harga saham menurun dan diikuti dengan nilai perusahaan yang menurun.

Pengaruh ukuran perusahaan terhadap nilai perusahaan dengan kepemilikan institusional sebagai pemoderasi di Indonesia. Hal ini berarti besarnya kepemilikan institusional dalam suatu perusahaan tidak mampu memperkuat pengaruh ukuran perusahaan terhadap nilai perusahaan. Dari hasil hipotesis H3 mengenai pengaruh ukuran perusahaan terhadap nilai perusahaan didapatkan ukuran perusahaan tidak berpengaruh terhadap nilai perusahaan, sehingga besar kecilnya proporsi kepemilikan institusional suatu perusahaan tidak bisa mempengaruhi pengaruh ukuran perusahaan terhadap nilai perusahaan.

Analisis multigrup pada penelitian ini digunakan untuk menguji perbedaan pengaruh determinasi nilai perusahaan di Indonesia dan Filipina dengan kepemilikan institusional sebagai pemoderasi, dengan hasil sebagai berikut : 


\section{Hasil Analisis Multi grup di Indonesia dan Filipina}

\begin{tabular}{llll}
\hline \multicolumn{1}{c}{ Variabel } & \multicolumn{1}{c}{$\boldsymbol{T m}$} & \multicolumn{1}{c}{$\boldsymbol{P m}^{\prime}$} & \multicolumn{1}{c}{ HasilAnalisis } \\
\hline Profit ->Firm.Val & 2.0469 & $0.0417^{*}$ & Signifikan \\
Solv ->Firm.Val & 0.3693 & 0.7122 & Tidak Signifikan \\
T.A ->Firm.Val & 2.7519 & $0.0063^{*}$ & Signifikan \\
KI ->Firm.Val & -2.4971 & $0.0131^{*}$ & Signifikan \\
Profit*KI & & & \\
>Firm.Val & -5.8462 & $0.0000^{*}$ & Signifikan \\
Solv*KI ->Firm.Val & -0.8666 & 0.387 & Tidak Signifikan \\
T.A*KI -> Firm.Val & 1.1225 & 0.2627 & Tidak Signifikan \\
\hline
\end{tabular}

Sumber :Analisis Multi grup (Excel) *) tingkat signifikansi 5\%

Berdasarkan hasil analisis multi grup yang dilakukan untuk menguji apakah ada perbedaan pengaruh profitabilitas, solvabilitas, ukuran perusahaan terhadap nilai perusahaan dengan kepemilikan institusional sebagai pemoderasi di Indonesia dan Filipina terbukti bahwa terdapat perbedaan antara kedua Negara. Variabel profitabilitas, ukuran perusahaan, kepemilikan institusional dan profitabilitas terhadap nilai perusahaan dengan kepemilikan institusional sebagai pemoderasi.

Perbedaan antara di Indonesia dan Filipina dapat dilihat dari hasil pengujian hipotesis, dimana pada variabel ukuran perusahaan dan kepemilikan institusional di Indonesia tidak berpengaruh terhadap nilai perusahaan, berbeda dengan di Filipina dimana variabel ukuran perusahaan dan kepemilikan institusional di Indonesia berpengaruh terhadap nilai perusahaan.Hasil yang berbeda juga dapat dilihat dari pengujian kepemilikan institusional, dimana di Indonesia kepemilikan institusional tidak berpengaruh terhadap nilai perusahaan tetapi variabel ukuran perusahaan dapat dimoderasi oleh kepemilikan institusional. Sedangkan di Filipina kepemilikan institusional berpengaruh terhadap nilai perusahaan dan ukuran perusahaan dapat dimoderasi oleh kepemilikan institusional dalam pengaruhnya terhadap nilai perusahaan.

\section{Kesimpulan, Keterbatasan dan Saran}

Tujuan penelitian ini adalah untuk menganalisis determinasi pengaruh variabel profitabilitas (ROA, ROE dan NPM), solvabilitas (DAR dan DER), ukuran perusahaan terhadap nilai perusahaan dengan kepemilikan institusional sebagai variabel pemoderasi. Sampel yang digunakan sebanyak 130 perusahaan yang masuk ke dalam index LQ45 di Indonesia dan 130 perusahaan yang masuk ke dalam index PSEi30 di Filipina.

Pengujian dilakukan dalam beberapa tahap, yaitu dengan pengujian outer model, pengujian model struktural tanpa variabel kontrol dan pengujian full model dengan variabel kontrol di Indonesia dan Filipina. Setelah itu juga dilakukan analisis multigrup untuk mengetahui apakah ada perbedaan pengaruh determinasi profitabilitas (ROA, ROE dan NPM), solvabilitas (DAR dan DER) dan ukuran perusahaan terhadap nilai perusahaan dengan kepemilikan institusional sebagai variabel pemoderasi.

Profitabilitas berpengaruh terhadap nilai perusahaan baik di Indonesia dan Filipina. Tingginya nilai profitabilitas pada suatu perusahaan akan meningkatkan EPS, EPS yang tinggi akan memberikan respon pasar yang positif sehingga permintaan akan saham meningkat. Permintaan saham yang meningkat akan mengakibatkan harga saham ikut meningkat, harga saham meningkat akan sejalan dengan peningkatan nilai perusahaan. Hasil penelitian ini sejalan dengan hasil penelitian terdahulu yang dilakukan oleh Irayanti \& Tumbel (2014) bahwa profitabilitas berpengaruh signifikan positif terhadap nilai perusahaan.

Solvabilitas tidak berpengaruh terhadap nilai perusahaan di Indonesia dan Filipina ditunjukkan dengan nilai P-Value $>0.05$. Hasil ini sejalan dengan penelitian yang sebelumnya dilakukan oleh Tommy dan Saerang (2014), Siahaan (2017), Mardiyati, dkk (2012) dan Dj, dkk (2012), dimana solvabilitas tidak memiliki pengaruh terhadap nilai perusahaan. Hal ini berarti saat tingkat solvabilitas tinggi perusahaan tidak akan mampu meningkatkan laba perusahaan, laba yang rendah maka akan 
menurunkan EPS. EPS yang rendah akan memberikan respon yang negatifdipasar, harga saham akan menurun atau tetap, sehingga nilai perusahaan pun akan menurun atau tetap.

Ukuran perusahaan tidak berpengaruh terhadap nilai perusahaan di Indonesia, hasil ini mendukung hasil penelitian yang dilakukan oleh Dewi \& Wirajaya (2013), dimana ukuran perusahaan tidak berpengaruh terhadap nilai perusahaan. Hal ini berarti total aset yang tinggi akan mengakibatkan suatu perusahaan tidak mampu menghasilkan laba, dikarenakan aset yang tinggi juga berarti biaya pemeliharaan yang tinggi, biaya penyusutan, dan lain-lain. Laba yang rendah mengakibatkan EPS yang rendah pula, respon yang negatif di pasar, sehingga tidak ada permintaan saham, hal ini mengakibatkan harga saham menurun atau tetap dan nilai perusahaan akan ikut menurun atau tetap. Sedangkan di Filipina ukuran perusahaan berpengaruh terhadap nilai perusahaan, hal ini sejalan dengan hasil penelitian dari Mawati, dkk (2017), Tommy dan Saerang (2014) dan Siahaan (2017) bahwa ukuran perusahaan berpengaruh signifikan terhadap nilai perusahaan. Ukuran perusahaan yang besar akan membuat para investor yakin untuk menanamkan modalnya, dengan kata lain nilai saham akan meningkat, dan nilai perusahaan ikut meningkat juga.

Kepemilikan institusional mampu memoderasi pengaruh profitabilitas terhadap nilai perusahaan di Indonesia, hal ini berarti semakin tinggi profitabilitas diikuti dengan besarnya kepemilikan institusional suatu perusahaan maka akan meningkatkan nilai perusahaan. Hal ini menunjukkan dengan adanya kepemilikan oleh institusional ditambah dengan profitabilitas yang tinggi maka akan meningkatkan produktivitas perusahaan, sehingga memberikan sinyal positif bagi para investor, permintaan akan saham akan meningkat, harga saham ikut meningkat dan nilai perusahaan akan meningkat pula. Sedangkan di Filipina kepemilikan institusional mampu memoderasi pengaruh profitabilitas dan ukuran perusahaan terhadap nilai perusahaan. Hal ini berarti dengan kepemilikan institusional ditambahkan dengan nilai profitabilitas yang tinggi dan besarnya ukuran perusahaan di Filipina dapat meningkatkan nilai perusahaan di mata investor.

Hasil analisis multigrup menunjukkan bahwa terdapat perbedaan determinasi pengaruh profitabilitas, ukuran perusahaan, kepemilikan institusional dan kepemilikan institusional yang mampu memoderasi pengaruh profitabilitas terhadap nilai perusahaan antara perusahaan di Indonesia dan Filipina.

Penelitian yang dilakukan oleh peneliti tidak terlepas dari keterbatasan yaitu peneliti hanya menggunakan sampel, yaitu perusahaan yang masuk ke dalam index LQ45 di Indonesia dan PSEi30 sebanyak masing-masing 26 Negara selama 5 tahun pengamatan (2012-2016).Selain ituvariabel yang digunakan peneliti adalah profitabilitas (ROA, ROE dan NPM), solvabilitas (DAR dan DER), ukuran perusahaan dan kepemilikan institusional. Selain variabel tersebut masih banyak variabel lain yang dapat mempengaruhi nilai perusahaan, seperti GCG, kebijakan deviden dan faktor lainnya.

Dari hasil penelitian dan keterbatasan penelitian, peneliti memberikan saran untuk peneliti selanjutnya dapat menambahkan variabel lain yang tidak digunakan di dalam penelitian ini yang dapat mempengaruhi nilai perusahaan.Pada penelitian ini menggunakan variabel kontrol yaitu variabel ekonomi makro yaitu GDP per capita, Economic Growth, Inflation Rate dan Exchang Rate dimana hasilnya tidak signifikan, bagi peneliti selanjutnya untuk tidak menggunakan variabel ekonomi makro sebagai variabel kontrol.Bagi peneliti selanjutnya dapat memperluas cakupan Negara yang diteliti, seperti Singapura, Bangkok, Kamboja dan Negara lain yang masih masuk ke dalam ASEAN.

\section{Daftar Referensi}

Agustini, R. R. (2015). DampakImplementasiRgecTerhadapNi lai Perusahaan Yang Go Public Di Bursa Efek Indonesia.

Ali, H., \&Miftahurrohman, M. (2014). Pengaruhstrukturkepemilikansaham, kebijakandividendankebijakanhutangte rhadapnilaiperusahaan

(studipadaperusahaan yang terdaftar di bei). Etikonomi, 13(2).

Ayuningrum, N. (2016). Analisis Pengaruh Profitabilitas dan Struktur Kepemilikan terhadap Nilai Perusahaan pada Perusahaan BUMS yang terdaftar di Bursa Efek Indonesia. Jurnal ACSY: Jurnal Accounting Politeknik Sekayu, 5(2), 1-8.

Dewi, A. S. M., \& Wirajaya, A. (2013). Pengaruh struktur modal, profitabilitas dan 
ukuran perusahaan pada nilai perusahaan. E-jurnalAkuntansi, 358-372.

Dini, A. W., \&Indarti, I. (2012). Pengaruh Net Profit Margin (NPM), Return On Assets (ROA) Dan Return On Equity (ROE) TerhadapHargaSaham Yang TerdaftarDalamIndeksEmiten LQ45 Tahun 2008-2010. Jurnal Kajian Akuntansi dan Bisnis, 1(1).

Dj, A. M., Artini, L. G. S., \& Suarjaya, A. G. (2012). Pengaruh kinerja keuangan terhadap nilai perusahaan pada perusahaan manufaktur di Bursa Efek Indonesia. Matrik: Jurnal Manajemen, Strategi Bisnis dan Kewirausahaan.

Hoque, J., Hossain, A., \& Hossain, K. (2014). Impact Of Capital Structure Policy On Value Of The Firm-A Study On Some Selected Corporate Manufacturing Firms Under Dhaka Stock Exchange. Ecoforum Journal, 3(2), 9.

Irayanti, D., \& Tumbel, A. L. (2014). Analisis kinerja keuangan pengaruhnya terhadap nilai perusahaan pada industri makanan dan minuman di BEI. Jurnal EMBA: Jurnal Riset Ekonomi, Manajemen, Bisnis dan Akuntansi, 2(3).

Mardiyati, U., Ahmad, G. N., \& Putri, R. (2012). Pengaruh kebijakan dividen, kebijakan hutang dan profitabilitas terhadap nilai perusahaan manufaktur yang terdaftar di Bursa Efek Indonesia (BEI) periode 2005-2010. JRMSI-

JurnalRisetManajemenSains Indonesia, 3(1), 1-17.

Mawati, E. R., Hardiningsih, P., \&Srimindarti, C. (2017). Corporate Governance Memoderasi Earnings Management danProfitabilitasTerhadapNilai Perusahaan.

Munawaroh, A., \&Priyadi, M. P. (2014). Pengaruhprofitabilitasterhadapnilaiper usahaandengan corporate social responsibiltysebagaivariabel moderating. JurnallmuERisetAkuntansi, 3(4), 1-17.

Prasetyorini, F., \&Fitri, B. (2013). Pengaruhukuranperusahaan, leverage, price earning ratio danprofitabilitasterhadapnilaiperusaha an. JurnalIlmuManajemen (JIM), 1(1).
Putri, R. H., Zahroh, Z. A., \& Wi Endang NP, M. G. (2016). Pengaruh Rasio Likuiditas Dan Rasio Profitabilitas Terhadap Nilai Perusahaan (Studi Pada Perusahaan Sektor Industri Barang Konsumsi Yang Terdaftar Di Bei Tahun 20122014). JurnalAdministrasiBisnis, 38(2), 38-45.

Ruan, W., Tian, G., \& Ma, S. (2011). Managerial ownership, capital structure and firm value: Evidence from China's civilianrun firms. Australasian Accounting, Business and Finance Journal, 5(3), 73-92.

Samosir, H. E. (2017). PengaruhProfitabilitasdanKebijakanUt angterhadapNilai Perusahaan yang terdaftar di Jakarta Islamic Index (JII). Journal of Business Studies, 2(1), 7583.

Siahaan, F. O. (2017). The effect of good corporate governance mechanism, leverage, and firm size on firm value. GSTF Journal on Business Review (GBR), 2(4).

Suratno. (2017), MengukurNilai-Nilai Perusahaan

MelaluiPendekatanIntegratifdanKompr ehensif. Jilid I. Publika Global Media. Yogyakarta

Suta, I. W. P., Sugiarta, I. N., \& Agustina, P. A. A. (2017). Pengaruh Kebijakan Utang Pada Nilai Perusahaan Dengan Kepemilikan Institusional Sebagai Variabel Moderasi (Studi pada Perusahaan Manufaktur di Bursa Efek Indonesia). Jurnal Bisnis Dan Kewirausahaan, 12(3 November), 173.

Tommy, P., \& Saerang, I. S. (2014). Struktur Modal, Ukuran Perusahaan Dan Risiko Perusahaan Terhadap Nilai Perusahaan Otomotif Yang Terdaftar Di Bei. Jurnal EMBA: Jurnal Riset Ekonomi, Manajemen, Bisnis dan Akuntansi, 2(2).

Wibowo, S., \& Tampubolon, L. D. (2016). Pengaruh CSR Disclosure dan GCG terhadap Nilai Perusahaan dengan Kinerja Keuangan sebagai Variabel Intervening di Perusahaan Manufaktur yang Terdaftar di Bursa Efek Indonesia (2012-2014).

Yusrianti, H., Habsari, T. N., \&Prukumpai, S. (2016). The Effect of Financial and Non- 
Mia Julia Putri : Determinan Nilai Perusahaan Publik di Indonesia dan Filipina dengan Kepemilikan Institusional sebagai Pemoderasi

Financial Variables to Firm Performance: Comparison Between Indonesia and Thailand. Journal of Accounting and Investment, 17(2), 118131. 